\title{
Evidencing Gatekeeping Relations through Narrativity
}

\author{
João Vasco Coelho ${ }^{1 *}$ \\ ${ }^{1}$ Centre for Research and Studies in Sociology (CIES), University Institute of Lisbon (ISCTE), 1649-026 Lisbon, \\ Avenida das Forças Armadas, Portugal \\ * Corresponding author, e-mail: vasco.jcoelho@gmail.com
}

Received: 18 March 2020, Accepted: 19 June 2020, Published online: 02 December 2020

\begin{abstract}
Seeking to illustrate the social processes involved in the research activity of gaining access to specific empirical contexts, this paper suggests the appropriateness of using narratives as analytical anchors, to explore and document the social relations maintained with and within business companies used as case studies, in the context of intensive, qualitative research endeavors. A doctoral research project focusing on studying business expatriation practices used in Portuguese multinational companies, is used as reference. This project development was punctuated by field access constraints and reluctant gatekeeping interactions, as well as unplanned research circumstances that implied the continuous negotiation of the research program's overall feasibility conditions. This paper discusses the plausibility of using narratives to illustrate, from an inside-out perspective, the social embeddedness of research projects involving sensitive topics and reluctant gatekeepers. Anchored in the use of a specific research narrative, five factors are discussed as possible field sites access enablers, arguing that the use of narratives can represent a gain for research processes discussion, providing increased methodological reflexivity opportunities.
\end{abstract}

\section{Keywords}

qualitative research, field access, gatekeeping, narrative analysis, reflexivity

\section{Introduction}

The main goal of the present paper is to share a methodological reflection concerning a doctoral research experience, where the creation and maintenance of field access conditions to a particularempirical researchfield(business expatriation practices used in Portuguese multinational companies) emerged as a sensitive question. In its theoretical underpinnings, the above mentioned doctoral research aimed to problematize global work practices observed in business internationalization contexts (Baruch et al., 2013; Kraimer et al., 2016; Mayrhofer et al., 2012; Shaffer et al., 2012), in two complementary analytical dimensions: a specific mode of performing and organizing work in transnational business settings, and a lived individual experience, open to subjectivation practices. In this doctoral research, a concrete global work practice was adopted as concrete empirical reference: business expatriation assignments (Dabic et al., 2015).

Business internationalization, the globalization of national economies and free circulation of people and goods on a global scale have contributed to the increased use of different forms of global work. Expatriation assignments, involving "employees who are temporarily relocated by their organizations to another country to complete a specific task or accomplish an organizational goal" (Shaffer et al., 2012:p.1287), are increasingly used by business organizations to anchor or secure international projects or operations deployment. The number of expatriates worldwide amounted to a total of 66.2 million in 2017 - this figure grew at a compound annual rate of $5.8 \%$ between 2013 and 2017 and is forecasted to reach an estimated 87.5 million by 2021, thereby growing at a compound annual rate of $7.2 \%$ (Finnacord, 2018).

Accessing and maintaining access to an empirical research site constitute one of the most common issues when performing business or organizational research work (Adler and Adler, 2002; Buchanan et al., 1988; Czarniawska, 2014; Feldman et al., 2003; Shenton and Hayter, 2004; Thomas, 1993; Welch et al., 2002). In the words of Burgess (1984), field access, and, in particular, obtaining and maintaining access conditions, is a quintessential success driver regarding the materialization of a research program. Despite this pivotal relevance, little tends to be said and shared about this activity, as when conceiving a research project design or reporting research processes and results, the creation of field access conditions tends to be considered 
as a minor step, of tactical importance (Gummesson, 2000), a taken-for-granted activity, being rarely accounted as a topic to be considered, reported on, or critically analyzed by researchers (Okumus et al., 2007).

Seeking to question and document the social processes that may arise within a researcher's quest for accessing an empirical research field, the present paper suggests the use of narratives as a communication tool and methodological device, addressing the adequacy of this use by discussing and presenting a narrative account created to mirror the trajectory of a doctoral research program whose implementation soon became full of limitations, detours and delays, in comparison with its original plans.

A concrete narrative is therefore used to identify field access enablers, and to anchor discussion concerning the plausibility of using narratives to portray social research relations marked by restrictions. A phenomenological, inside-out perspective, is adopted, in light of similar reports from case studies conducted in business and organizational context, where, to a certain extent, field access to both companies and individuals within companies represented a research planning issue (Adler and Adler, 2002; Buchanan et al., 1988; Burawoy and Lukács, 1992; Feldman et al., 2003; Laurila, 1997; Thomas, 1993; Okumus et al., 2007; Quattrone, 2006; Shenton and Hayter, 2004; Welch et al., 2002).

\section{Gaining field access as research problem: a theoretical outline}

A research plan deployment may be subject to unexpected constraints (Czarniawska, 2007, 2014; Denzin and Lincoln, 2000). This circumstance demands maintaining an open-minded and flexible positioning toward the planning of research activities, in what concerns, for instance, choosing and adjusting means of contact, negotiating interview and direct observation time slots, people to be contacted, and the lengthy time needed to build (earn, in some cases) a sense of trust and confidence with the person (or persons) performing a gatekeeping role (Shenton and Hayter, 2004). Furthermore, research constraints may also include the need to introduce design changes, so that the study is accepted and perceived as relevant, useful or benign, or the need to reflect upon the role carried out by the researcher itself, with regards to the interference effect possibly generated by its presence in the empirical setting that is being observed.

One specific constraint of the doctoral research considered in the present paper arose from the supposedly sensitive nature (Lee, 1993) of the research topic being considered (business expatriation practices and personal experiences observed in Portugal), from which significant and unforeseen research planning restrictions were generated. As mentioned by authors such as Shaffer et al. (2012), deploying business expatriation practices and managing differentiated (and differentiating) expatriate experiences (still) represent a sensible weakness in a managerial perspective, while simultaneously playing a decisive role in the implementation of a company's internationalization strategy. Portugal is not an exception in this regard, with empirical reports describing expatriation management practices as being reactive, centripetal and mainly compliance-driven, with scarce attention being given to expatriate adjustment and repatriation (Câmara, 2011).

The sensitive nature of a research topic is a particularly significant occurrence in a business context, given that empirical field sites tend to be seen and considered as being nominally closed, constituting a private universe whose (good) public image must be maintained at all cost (Laurila, 1997). Moreover, obtaining access in and within business contexts can imply additional technical and specific challenges, such as the geographical dispersion of existing facilities, the managerial conception of time as a finite (scarce) resource and production input, and the increased physical mobility of individuals in their daily work lives (Elliott and Urry, 2010). In this context, a request to gain entrance to a company's interiors can suggest, carry or imply a sense of intrusion and interference. To a certain degree, the access that may be granted within these conditions can constitute a type of conditional and restrained access to the front-end of the company, an antechamber, not its backbone or operational backstage (Czarniawska, 2014). Shenton and Hayter (2004) differentiate two levels of field access - organizational access and individual access within the organization - that can be subject to negotiation, in particular in the context of qualitative research projects involving interviews, direct observation, practitioner shadowing or other kind of direct exposure to what can be understood as a raw, unmediated slice of corporate or organizational reality.

Field access tends therefore to be a vital part of any qualitative research plan success and overall feasibility, and it is typically subject to control and regulatory processes (gatekeeping), which are thoroughly documented in the literature (Reeves, 2010). The gatekeeper is a/the organizational actor internally vested with a regulatory power, specially aimed to prevent access to information considered to 
be sensitive or confidential. When interacting with a gatekeeper, the researcher's positioning is typically unequal, in what concerns the detention of symbolic resources, domain knowledge, and decision-making leveraging ability. In practical or discursive terms, if analyzed in situ, the symbolic resources that a researcher is able to mobilize in an empirical observation setting, is the formal support of an actor or an institution of unquestionable reputation (Shenton and Hayter, 2004), its own experience and professional competency, and the personal credit that can be imported as a result of belonging to the academic community.

In facilitating field access, the gatekeeper takes risks, because, by guaranteeing access, credibility is given to the research study and, to some extent, social status is ascribed to the researcher, in what can be considered a situation that can jeopardize reputation and internal credibility. Given the role typically performed by a gatekeeper, one can affirm that, instead of a process that is aseptically reported, the researcher does not select a sample of companies, nor individuals within these companies, but, to a large extent, companies choose researchers and their research plans and intentions. As emphasized by Costa (1986), the ability to see and speak from the inside is always determined by whatever the social group allows to be seen.

An in-depth description of these processes and its implications can be found in the "sociological diary" made by Burawoy and Lukács (1992:p.5) to describe the lengthy process that ensure access to portrait how Hungarian workers could be experiencing communism "radiant future". Starting by framing their research intents as "discovering the impossible", "knowing how politically sensitive were questions about the working class", "time" and "personal connections" were key to "unlock bureaucratic doors", and allow field access via work permits obtained in "county level offices of the Ministry of the Interior", with "favors" being asked to privileged contacts by someone understood as credible. A maze of "reciprocal ties" and "primitive gift exchanges" was decisive to ensure field access, a "bungled" process (Burawoy and Lukács, 1992:p.11), as described by Burawoy (2013:pp.529-530) in a later paper: "Factories were never easy to access for an alien sociologist, nonetheless I managed to wend my way from a champagne factory on a collective farm to a small cotton spinning shop on a cooperative farm and from there I managed to insinuate myself into a machine shop just like the one at Allis Chalmers. Finally, I entered the heart of the socialist working class, enrolling in the Lenin Steel Works of Miskolc where I worked as a furnace man for a total of 11 months in three stints between 1985 and 1989, that is, until state socialism disintegrated".

Methodological discussions concerning field access and gatekeeping relations often bring up aspects related with operational constraints, research feasibility (D'Andrea et al., 2011), and the need to obtain a precise sense of what is possible to obtain, when deciding upon theoretical-methodological options (Czarniawska, 2014). Fieldwork conducted in corporate and organizational contexts often reveal that field access constitutes a transversal problem to a research trajectory, not so much due to its intrinsic content, but as a social reality, a novelty factor which intrudes on the company's established routines. Access is not granted forever, and its concession is precarious, which requires the mobilization of a set of practices in order to maintain it (Brown et al., 1976; Feldman et al., 2003). In addition to this, organizational access does not necessarily include or inherently guarantee access to the individuals within an organization (Laurila, 1997; Lee, 1993). However, individual and/or localized access negotiations are possible, portraying an empirical study as a process of articulating apparently infinite contingencies (Lee, 1993). Unplanned field site access processes may mirror some of the fallacies researchers fall into, while or when observing workplace relations, or, using more general terms, the economy (Gregory and Altman, 1989; Hann and Hart, 2011). Burawoy synthetically illustrates these challenges (2013:p.527): "Three traps wait the ethnographer who fails to give the field site a dynamic of its own: the fallacies of viewing the field site as eternal or, when the past is examined, the danger of treating the present as a point of arrival rather than also as a point of departure; and finally the danger of wishful thinking, projecting one's own hopes onto the actors we study".

When accessing individuals within an organization, the impact of social positioning (Davies and Harré, 1990) or self-presentation processes (Goffman, 1959), and of localized identity (re)composition practices, is significant. In this context, it is important to consider liminality as a social positioning condition that is typically inherent to research activities. The researcher's liminal positioning (Borg and Söderlund, 2014) constitutes a possibility of detachment in relation to the set of formal roles maintained by individuals in a given social context. Attribution processes, related to who the researcher is and what or who their study represents (Becker, 1998), the motive behind choosing one individual in particular to interview (excluding others), and the reluctance of individuals to respond (Adler and Adler, 2002; Quattrone, 2006; Thomas, 1993), 
tend to define the interaction dynamics that condition observational processes and the nature of the information collected throughout the course of empirical observation. In Burawoy and Lukács (1992:p.12) mentioned "sociological diary" research activities social embeddedness is illustrated: "To gain entry (...), I would have to demonstrate that the research would produce profit for the company, whereas here I had to demonstrate that it wouldn't redound against the general director. As ever, entry, particularly when it is resisted and even bungled, reveals much about underlying social forces, even if these become understandable only later in the research process".

Due to this social embeddedness, field access negotiating is a process that should be considered transversal to the deployment of a research plan. The (long) duration of the social processes accompanying field access negotiations is a circumstance that shape situated research-related encounters and interactions (Goffman, 1961). Its thorough analysis implies a distancing exercise, a methodological practice that, in the words of Bourdieu (1972), calls on researchers to produce scientific knowledge on how knowledge is socially produced.

Using narratives (Cole, 2013; Czarniawska, 1997, 2004; Muncey, 2005; Riessman, 1993; Wall, 2006) as an expositive and communication vehicle, concerning a researcher's reflexive experience of the aforementioned research processes, can constitute a valuable resource to promote additional viewpoints over specific research circumstances, helping to stabilize connections and interpretative templates around these (Czarniawska, 2014). This use can help shed light on processes typically neglected in research reports (Okumus et al., 2007), due to ascribed minor importance (Gummesson, 2000), a perspective that can trigger the existence of unexpected research events and obstacles (Burawoy, 2013; Siwale, 2015).

\section{Methods and materials}

In its methodological orientation, the doctoral research used as reference in the presented paper adopted an intensive, qualitative approach to restricted empirical observation fields. Field sites access was granted to five Portuguese multinational private companies, operating in sectors (utilities, retail, management consultancy, construction, IT) (check Table 1, for details), with significant contribution the country's economic internationalization, due to consolidated international trajectories, expatriate management experience, and overall employment volume (500 to 40,000 employees). Field access negotiations lasted 14 months (January 2016 to February 2017).

In order to illustrate the social processes associated with the lengthy creation of field access conditions, a narrative was created from a set of fieldnotes registered throughout the research project. Fieldnotes can be seen as records of self-reflection practices (Alvesson et al., 2008; Cunliffe and Karunanayake, 2013), emerging in a context of constrained social relations. The presented narrative aims to report on and represent a way of viewing the social embeddedness of a specific research activity. In this sense, the presented narrative - "We will see what can be done"-attempts to illustrate, as research material and narrativity use case example, the concrete lived experience of a researcher seeking to obtain field access to concrete sites, an experience often neglected in methodological notes and reports shared by researchers (Okumus et al., 2007:p.2). The narrative portraits a field of constraints, reluctancy (Adler and Adler, 2002) and specific social

Table 1 Business Contexts (Source: Self-made).

\begin{tabular}{|c|c|c|c|c|c|c|c|c|c|}
\hline $\begin{array}{l}\text { Business } \\
\text { Sector }\end{array}$ & Governance & $\begin{array}{l}\text { Yearly Turnover } \\
\text { (2016) }\end{array}$ & $\begin{array}{c}\text { Number of } \\
\text { Employees } \\
(2016)\end{array}$ & $\begin{array}{c}\text { Founding } \\
\text { Date }\end{array}$ & $\begin{array}{c}\text { Start of } \\
\text { Internationalization } \\
\text { Process } \\
\text { (first year) }\end{array}$ & $\begin{array}{c}\text { International } \\
\text { Outreach } \\
\text { (number of } \\
\text { countries/markets) }\end{array}$ & $\begin{array}{c}\text { 1st } \\
\text { definition of } \\
\text { Expatriation } \\
\text { Policies }\end{array}$ & $\begin{array}{c}\text { Number of } \\
\text { Expatriate } \\
\text { Employees } \\
\text { (2017) }\end{array}$ & $\begin{array}{c}\% \\
\text { Expatriate } \\
\text { Employees } \\
(2017)\end{array}$ \\
\hline $\begin{array}{l}\text { Utilities - } \\
\text { Energy }\end{array}$ & $\begin{array}{l}\text { Private (with } \\
\text { a public } \\
\text { stakeholder) }\end{array}$ & 3.759 million euros & 12,000 & 1976 & 1996 & 14 countries & 2014 & 25 & $(<1 \%)$ \\
\hline $\begin{array}{l}\text { Retail and } \\
\text { Distribution }\end{array}$ & Private & 5.376 million euros & 44,000 & 1959 & 1990 & 89 countries & 2012 & 30 & $(<1 \%)$ \\
\hline $\begin{array}{l}\text { Management } \\
\text { Consulting }\end{array}$ & Private & 80.2 million euros & $\begin{array}{l}244,000 \\
(2,300 \mathrm{in} \\
\text { Portugal })\end{array}$ & 2002 & 1993 & $\begin{array}{l}150 \text { countries } \\
\text { (presence in } \\
\text { Portugal) }\end{array}$ & 2013 & 100 & $4.35 \%$ \\
\hline Construction & Private & 2.210 billion euros & 25,383 & 1946 & 1946 & 25 countries & 2010 & 1264 & $4.98 \%$ \\
\hline $\begin{array}{l}\text { IT - Software } \\
\text { Development }\end{array}$ & Private & 30 million euros & 400 & 1998 & 1999 & 5 countries & 2009 & 41 & $10.25 \%$ \\
\hline
\end{tabular}


positioning with regards to a specific empirical context (Ragin and Becker, 1992). It is conceived to constitute, itself, a research output, an enigma yet to be decoded and interpreted by the researcher.

\section{"We will see what can be done".}

A research plan is crafted. Relevant cases, in light of the problem being examined, are identified. A shortlist of companies and individuals in companies is made. Contacts, phone calls are made. Someone knows someone who knows someone that works or used to work in the listed companies. A first email is sent - an introduction to the study, a specific collaboration request. Concurrently, whether intentionally or fortuitously, a helpful side contact, highlights the email content, making it salient, distinctive (from others).

That request was not just one more request. The e-mail is answered. A second email is sent, which thoroughly details the research objectives, and the profile of the researcher. A phone contact is scheduled, and later on rescheduled. The phone contact takes place, mediated by an assistant. A waiting period takes place. Twenty, thirty, fifty minutes. The phone call is passed to another assistant: the study's goals, utility, degree of intrusion and interference, is described. A follow-up contact is scheduled, aimed to prepare a face-to-face meeting (a manager presential interview, the key goal of the initial contact), and get prior confirmation of the topics to be discussed. The interview is scheduled for one or two months in the future. The interview is rescheduled one week beforehand, or the day before it was supposed to occur. It will take place at a different time, at a different place, in a different city. The company, is said, is doing "what can be done". The presential interview finally takes place. There is an ever-present feeling of discomfort that emanates from the power inequality of the situation, characterized by the apparent total dependence of the "observer" in relation with the "observed". New difficulties arise on the interview day. Physical access problems occur ("You are in the correct location, but this is the back entrance of the company"). Identity, identification, counter-identification issues, identity becoming an issue ("What company are you from? Who should I let know that you are here? What is the purpose of the meeting? What is the name of the person who you are looking for?"; "How to physically recognize the person one is looking for?"). The researcher presents itself at the reception, in a hall, at a desk - an antechamber. A waiting period takes place. The interviewee is delayed. Half-an-hour, an hour, an hour-and-a-half. Generic background music can be heard. There are job applicants, suppliers, friends who are also waiting. Customers don't wait on antechambers. On the walls, "transparency" and "closeness" values are cheerfully proclaimed as ethical principles and constitutive motives of the company's business strategy and organizational culture. Face-to-face contact finally occurs. The surrounding physical space is impersonal. None of the parties knows where to charge a phone. None of the parties belongs to that place of physical encounter. Once again, the researcher presents the purpose of the research, the interview, its utility, its commitment to anonymity and confidentiality, its background. Permission to use a tape recorder is requested. It is mentioned that it will be necessary to get higher approval to do so. A new waiting period occurs. Permission is granted, in light of the declared intent to later share the generated empirical materials for corporate approval. The researcher persists on presenting the research as inoffensive, perhaps even ultimately useful to the company, to the interviewer. Over the course of the interview, reproductions of institutional discourse and an overall sense of reluctancy to respond come across as preferred modes of expression. A powerpoint presentation is used by the interviewee. The researcher tries to reposition its use: "What the powerpoint says is important, but research wise it is more relevant to understand what you have to say about the powerpoint". Phone calls and messages, physical interruptions keep cutting the meeting short. "Sorry, we have to finish this". The interview ends. The researcher asks about the chance to access specific documentation, in addition to what is already made public by the company. "That will be difficult, but we will see what can be done". New contacts will be made to schedule new interviews, most probably generating new needs to explain in-depth the research goals and scope. While leaving the company facilities, while waiting for a taxi, a vague and ambiguous sense of inadequacy and embarrassment resonates in the researcher's mind.

\section{Results: gatekeeping and field site access enablers}

In the research initial planning, field access (to companies and individual interviewees in companies) was targeted as an activity that would last three months, possibly involving further follow-up leveraging interactions. Field access negotiations came to last a total of 14 months (January 2016 to February 2017), a long and iterative relational process, that implied successive adaptations 
regarding the research's initial design. Within this time interval, 14 interviews with managers and company directors were conducted, in 5 Portuguese multinational private companies, operating in different sectors (utilities, retail, management consultancy, construction, IT), with different outputs and efficiency.

During these interviews, scripted and refrained discourse, interactions targeted and framed by memos or powerpoint bullets, signaled that the topic being considered was perceived as sensitive, in a managerial perspective. Two levels of gatekeeper and gatekeeping relations were identified:

1. gatekeeping related with overall access to the company (typically, company board administrators and first-line directors acted as gatekeepers);

2. gatekeeping related with access to workers, within the company (departmental directors and middle managers acting as gatekeepers).

During the 14-month period, access to a sixth company (micro-electronics) was first delayed, and later on denied, as the research topic (expatriation management practices and personal expatriate experiences) was considered a sensitive issue, and, as result of this, accessing expatriate individuals (after or during their expatriation assignments) was considered "inopportune" by the first-line gatekeeper (the company's HR Director). During this time span, different research initial options were discarded (e.g., the use of participant observation or field diaries as empirical material collection techniques). In accordance with these (un)successful access results, the initial research plan was successively revised over the course of the aforementioned time period.

Substantial unplanned effort was put in the process of finding gatekeepers in each business context. Silence was the most common result to initial phone or e-mail contact attempts. Success was only achieved when backdoor, personal acquaintances driven by someone understood as credible were used to triangulate access and, in particular, to identify an appropriate person or department to connect with. For the considered field sites, access to the company was facilitated or triangulated by privileged personal connections of the researcher, a lengthy process involving several phone calls to present the research (and the researcher), and endless e-mail exchanges. Access to each site encompassed an average of 30 e-mails being exchanged, and, in one case (retail company), involved 80 e-mails exchanged over 6 months.

In what concerns access request results, in one of the companies (management consultancy), the researcher was allowed to conduct interviews with two expatriate individuals (100 was the total universe of business expatriates) (check Table 1 for details). In the retail company, this access was not granted, as these individuals were not "that many", and did not have "anything relevant to say" (HR Director). In the remaining three companies, five to eleven individual expatriate in-depth interviews were performed (a total of 24 individual expatriate interviews were made). In the construction company, access to lowskilled expatriates (out of a universe of 1,264) was not conceded. In this context, hearing these workers was told by first and second-line gatekeepers (HR Directors and Managers, respectively) as not necessary or adequate, as they were "far away", should not "be bothered", and ultimately had "nothing relevant" to add regarding their lived experiences. Overall, on the grounds of its omniscience, gatekeepers tended to speak on behalf of workers - they knew the needs of the people and represented their interests. As suggested by Burawoy (1985), management can presciently take over working lives and working lives accounts as a distinctive social institution.

Supported by the "We will see what can be done" narrative and research fieldnotes compiled regarding managerial endeavors and gatekeeping discourse, five factors or conditions were identified as possible field access enablers, in qualitative organizational studies involving sensitive topics:

1. The pivotal role played by social network capital. This is a factor closely linked with the importance of attracting formal support from an actor or institution with unquestionable reputation - the known sponsor, using Shenton and Hayter (2004) terms. In the present case, this was anchored and ensured by a network of close personal and professional contacts, which was mobilized by the researcher as a strategic resource to leverage access to research field sites. Backdoor references, phone calls and emails were decisive in mobilizing this network, as illustrated in the narrative: "Someone knows someone who knows someone that works or used to work in the listed companies. A first email is sent - an introduction to the study, a specific collaboration request. Concurrently, whether intentionally or fortuitously, a helpful side contact highlights the email content, making it salient, distinctive (from others). That request was not just one more request. The e-mail is answered".

2. Being ready. It was crucial to be (always) ready and prepared to present the research intents, possible benefits (for a company), and the researcher profile, personal and professional trajectory. Preparation is opposed to improvisation or momentary inspiration. 
Preparation is important to promptly demonstrate congruence with representations, practices in use or cultural preferences of the gatekeeper and the company. This preparation implied an investment in obtaining contextual knowledge and learning about the different companies considered as field sites, their history and modes of organization (e.g., international expansion, organizational practices, core products and services), and about the interlocutors selected internally to establish gatekeeping relations (LinkedIn public data was used as proxy, in this regard). Readiness proved to be especially relevant during contacts with first-line gatekeepers, which aimed to determine the nature of the access to be granted to the researcher - the getting in phase, according to Buchanan et al. (1988).

3. Demonstrating social and cultural isomorphism. Readiness aimed to provide a general impression of benign appropriateness (of the research and the researcher), to be highlighted by the researcher, in the context of remote or face-to-face interactions. Depending on the identification of representations, practices in use or cultural preferences, social spaces could be put in practice by the researcher. In general terms, sociocultural preferences for isomorphism were identified during initial interactions (phone calls and e-mails), suggesting the need to discursively neutralize the study and the researcher as possible sources of intrusion and threat. The use of rapport, echo and mirror interviewing techniques, of native language, the demonstration of interest in what was, in particular, declared by each interlocutor, were relevant to ground interactions and research intentions as being benign. As illustrated in the presented narrative: "Once again, the researcher presents the purpose of the research, the interview, its utility, its commitment to anonymity and confidentiality, its background. (...) The researcher persists on presenting the research as inoffensive, perhaps even ultimately useful to the company, to the interviewer. (..) A powerpoint presentation is used by the interviewee. The researcher tries to reposition its use: What the powerpoint says is important, but research wise it is more relevant to understand what you have to say about the powerpoint".

4. Making use of liminality. The use of a temporary inside-outsider positioning (Borg and Söderlund, 2014), emerged as a social process where liminality represented, simultaneously, a constraint and a field of beneficial possibilities to be explored. The researcher tended to be viewed as an outsider, a stranger. This injunction typically established an empty space to be filled, a putative advantage for the researcher, if put in practice as possibility that allows freedom to escape stereotyping and managerial encapsulation of its action. In the present case, the experience of this condition was, in particular, associated with "a feeling of discomfort" emanating from "the power inequality of the situation, characterized by the apparent total dependence of the 'observer' in relation with the 'observed'".

5. Maintaining openness and flexibility. Regarding the need to iterate over research strategic options, research social embeddedness presented gaining field access interactions as trading arenas. Lack of intrusion to existing internal order and the search for benefits for the company tended to frame the tone and the direction of gatekeeping relations. A significant stream of empirical data stemmed from the questions asked to the researcher, the redefinition of social relations produced by his presence. To leverage this, it was crucial to maintain a flexible approach in relation to the research process. This openness and flexibility were ultimately translated into the consideration of the research plan as an emerging, bottom-up reality, and the need to design contingency scenarios to the research design initially taken as preferential.

\section{Discussion: gatekeeping and the methodological relevance of using narrative accounts}

A narrative is not just an opinion, a piece of data, a text or a platitude, constituting a composition created from a set of collected empirical references. In the context of qualitative research, the singular, illustrative nature of this composition can be considered the key motive for its use as an analytical resource (Riessman, 1993). A narrative account allows one to understand how an individual put himself in-context, acting as a subject-object of observation, rationalizing events by embedding them in the effect of autobiographical references (Czarniawska, 2004).

In the doctoral research reported by the present paper, the appropriateness of using narratives as an analytical device is particularly explained by the need (and the opportunity) to showcase and promote methodological reflection around the specificity of a research activity - the field access moment, a stage that tends to involve a degree of 
negotiation and empirical confrontation. As mirrored by the different factors suggested in Section 4 as possible field access enablers, field access, in phenomenological terms, can arise as a confrontational experience accompanied by social discomfort, but, despite this, it constitutes a key activity to execute a research plan like the one reported by the presented paper - a qualitative research design, taking place in business settings, focused on topics considered or conceived internally as being sensitive (Lee, 1993).

Composing the narrative "We will see what can be done" implied a cursory exercise of critical and subjective distancing to the object, process or social phenomenon being considered (Czarniawska, 2004, 2014). In a lived perspective, an overall sense of constraint emphasizes the liminal position (Borg and Söderlund, 2014) of the researcher, in relation to the social group or reality used as reference of empirical observation. Liminality created a social distancing condition, available to be leveraged by the researcher to escape the confinement of social and organizational action established by existing routines. By identifying social representations and cultural preferences commonly used by the gatekeeper (e.g., research as [being] inoffensive), research interactions and social distances can be leveraged by the researcher as tactical or strategic advantage: in the presented case, the researcher could mirror these preferences by creating a benign sense of isomorphism (demonstrating that the researcher's beliefs were similar to those held by the gatekeeper), as opposed to foster a sense of antagonism and cultural difference, using heteromorphism as possible field access trigger, a way to capture the gatekeeper's curiosity and interest about the proposed research.

Narrativity can also introduce an additional element of methodological reflexivity (Johnson and Duberley, 2003) in the research plan, and this can be carried by ploting events, talks and interactions emanating from researcher cursory actions and their impact in the social construction of the research process. The researcher's presence in field settings introduces nuances in pre-existent social relations and organizational routines (Czarniawska, 2014). Consequently, narrativity and methodological reflexivity can be relevant to identify the researcher's positioning in relation to the object being studied (Cunliffe and Karunanayake, 2013; Hibbert et al., 2010). As mentioned, "a feeling of discomfort" tended to stem from "the power inequality" of the researcher's positioning, in what can be considered an interference effect experienced in relation to the phenomenon being studied. This can be arrayed as an analytical dimension in further research endeavors.
During the development of the doctoral project reported by the presented paper, the choice to use narratives as research explanation vehicle resulted in increases in both visibility and chance for research scrutiny, due to the elicitation of critical incidents and the exploration of salient thematic domains, condensed and presented as field site access enabling factors. In this respect, the narrative "We will see what can be done" helps to illustrate, in an inside-out perspective, the lengthy attempt to access companies and erase to individuals within companies as an experience of constrain, a social process fundamentally marked by negotiation and unforeseen difficulty. In a methodological and epistemological perspective, this chance of increased research scrutiny can constitute a significant and valuable asset, in particular having in mind the secondary, invisible status typically given to the social and relational dimensions involved in qualitative research plans execution.

A narrative can be found between individuals, and not within individuals, implying an activity of situated interaction, dialogical practices shaped by the status of all involved parties. The reverberation produced by the asymmetry of social positions, the (liminal) positioning of the researcher, and the social representation of the research topic (Lee, 1993), influence, as described, the way individuals reconstitute the trajectory of a social process through the composition of a narrative. To some extent, one can suggest that when field access itself no longer represents a problem, a source of reverberation, intrusion or awkwardness, as expressed in the narrative "We will see what can be done", it is possible to consider that the moment to leave the field has arrived (Buchanan et al., 1988), putting an end to the experience of discomfort and strangeness. In this perspective, by capturing reverberation and constraint as lived experiences, narrative accounts emerge as plausible vehicles to convey scientific knowledge about social practices (e.g., conducting a doctoral research in an organizational or business setting), and, in particular, specific and critical stages, enabling events and incidents encompassed by these practices (e.g., gaining and maintaining field site access).

\section{Conclusion}

Seeking to illustrate the social processes involved in a specific research activity (gaining and maintaining field access, dealing with unforeseen constraint and gatekeeping relations), the appropriateness of using narratives to accomplish this goal stems from its close association with the conditions inherent to a research's social production, the contingencies arrayed as essential to the research 
process itself. As suggested in the present article, including narrativity in a research design can be particularly beneficial for projects involving sensitive topics and reluctant gatekeepers, representing a gain for the research process enablement, configuring a use case that provides increased methodological reflexivity opportunities, and a chance to scrutinize empirical observation procedural

\section{References}

Adler, P. A., Adler, P. (2002) "The reluctant respondent", In: Gubrium, J. F.,. Holstein, J. A. (eds.) Handbook of Interview Research, Sage Publications, Thousand Oaks, CA, USA, pp. 515-536.

Alvesson, M., Hardy, C., Harley, B. (2008) "Reflecting on Reflexivity: Reflexive Textual Practices in Organization and Management Theory", Journal of Management Studies, 45(3), pp. 480-501. https://doi.org/10.1111/j.1467-6486.2007.00765.x

Baruch, Y., Dickmann, M, Altman, Y., Bournois, F. (2013) "Exploring international work: types and dimensions of global careers", The International Journal of Human Resource Management, 24(12), pp. $2369-2393$.

https://doi.org/10.1080/09585192.2013.781435

Becker, H. S. (1998) "Tricks of the Trade: How to Think about Your Research While You're Doing It", University of Chicago Press, Chicago, IL, USA.

https://doi.org/10.7208/chicago/9780226040998.001.0001

Bourdieu, P. (1972) "Esboço de uma teoria da prática" (Outline of a theory of practice), Celta Editora, Oeiras, Portugal. (in Portuguese)

Borg, E., Söderlund, J. (2014) "Moving in, moving on: liminality practices in project-based work", Employee Relations, 36(2), pp. 182-197. https://doi.org/10.1108/ER-11-2012-0081

Brown, C., Monthoux, P., McCullough, A. (1976) "The access-casebook", Teknisk Hogskolelitteratur, Stockholm, Sweden.

Buchanan, D., Boddy, D., McCalman, J. (1988) "Getting In, Getting On, Getting Out and Getting Back", In: Bryman, A. (ed.) Doing Research in Organizations, Routledge, London, UK, pp. 53-67.

Burawoy, M. (1985) "The Politics of Production", Verso, London, UK.

Burawoy, M. (2013) "Ethnographic fallacies: reflections on labour studies in the era of market fundamentalism", Work, Employment and Society, 27(3), pp. 526-536. https://doi.org/10.1177/0950017012460316

Burawoy M., Lukács, J. (1992) "The Radiant Past: Ideology and Reality in Hungary's Road to Capitalism", University of Chicago Press, Chicago, IL, USA.

Burgess, R. (1984) "A pesquisa de terreno: Uma introdução" (In the field: An introduction to field research), Edições Celta, Oeiras, Portugal. (in Portuguese)

Câmara, P. (2011) "A expatriação em Portugal" (Expatriation in Portugal), Editora RH, Lisbon, Portugal. (in Portuguese)

Cole, C. E. (2013) "Stories from the lived and living fieldwork process", Qualitative Research in Organizations and Management, 8(1), pp. 50-69.

https://doi.org/10.1108/17465641311327513

Costa, A. F. (1986) "A pesquisa de terreno em Sociologia" (Field research in Sociology), In: Silva, A., Pinto, J. (eds.) Metodologia das Ciências Sociais, Afrontamento, Porto, Portugal, pp. 129-148. (in Portuguese) options and specific tactical issues involved in gaining field access activities.

\section{Acknowledgement}

The research project presented in this article was supported by FCT - Fundação para a Ciência e a Tecnologia.

Cunliffe, A., Karunanayake, G. (2013) "Working Within Hyphen-Spaces in Ethnographic Research: Implications for Research Identities and Practice", Organizational Research Methods, 16(3), pp. 364-392. https://doi.org/10.1177/1094428113489353

Czarniawska, B. (1997) "Narrating the Organization: Dramas of Institutional Identity", University of Chicago Press, Chicago, IL, USA.

Czarniawska, B. (2004) "Narratives in Social Science Research", Sage Publications Ltd., London, UK. https://doi.org/10.4135/9781849209502

Czarniawska, B. (2007) "Shadowing: And Other Techniques of Doing Fieldwork in Modern Societies", Copenhagen Business School Press, Copenhagen, Denmark.

Czarniawska, B. (2014) "Social science research", Sage, London, UK.

D'Andrea, A., Ciolfi, L., Gray, B. (2011) "Methodological Challenges and Innovations in Mobilities Research", Mobilities, 6(2), pp. 149-160. https://doi.org/10.1080/17450101.2011.552769

Dabic, M., González-Loureiro, M., Harvey, M. (2015) "Evolving research on expatriates: What is 'known' after four decades (1970-2012)", The International Journal of Human Resource Management, 26(3), pp. 316-337. https://doi.org/10.1080/09585192.2013.845238

Davies, B., Harré, R. (1990) "Positioning: The Discursive Production of Selves", Journal for the Theory of Social Behaviour, 20(1), pp. 43-63. https://doi.org/10.1111/j.1468-5914.1990.tb00174.x

Denzin, N. K., Lincoln, Y. S. (2000) "Handbook of qualitative research", Sage Publications, Thousand Oaks, CA, USA.

Elliott, A., Urry, J. (2010) "Mobile Lives", Routledge, London, UK.

Feldman, M. S., Bell, J., Berger, M. (2003) "Gaining access: A practical and theoretical guide for qualitative researchers", AltaMira Press, Walnut Creek, CA, USA.

Finnacord (2018) "Global Expatriates: Size, Segmentation and Forecast for the Worldwide Market", [online] Available at: https:/www.finaccord.com/Home/About-Us/Press-Releases/Global-ExpatriatesSize,-Segmentation-and-Forecas [Accessed: 17 March 2020]

Goffman, E. (1959) "The presentation of self in everyday life", Doubleday Anchor Books, New York, NY, USA.

Goffman, E. (1961) "Encounters: Two studies in the sociology of interaction", Bobbs-Merrill, Indianapolis, IN, USA.

Gregory, C. A., Altman, J. (1989) "Observing the Economy", Routledge, London, UK.

Gummesson, E. (2000) "Qualitative methods in management research", Sage, London, UK.

Hann, C., Hart, K. (2011) "Economic Anthropology: History, Ethnography, Critique", Polity, Cambridge, UK. 
Hibbert, P., Coupland, C., MacIntosh, R. (2010) "Reflexivity: recursion and relationality in organizational research processes", Qualitative Research in Organizations and Management, 5(1), pp. 47-62. https://doi.org/10.1108/17465641011042026

Johnson, P., Duberley, J. (2003) "Reflexivity in Management Research", Journal of Management Studies, 40(5), pp. 1279-1303. https://doi.org/10.1111/1467-6486.00380

Kraimer, M., Bolino, M., Mead, B. (2016) "Themes in Expatriate and Repatriate Research over Four Decades: What Do We Know and What Do We Still Need to Learn?", Annual Review of Organizational Psychology and Organizational Behavior, 3, pp. 83-109. https://doi.org/10.1146/annurev-orgpsych-041015-062437

Laurila, J. (1997) "Promoting research access and informant rapport in corporate settings: Notes from research on a crisis company", Scandinavian Journal of Management, 13(4), pp. 407-418. https://doi.org/10.1016/S0956-5221(97)00026-2

Lee, R. M. (1993) "Doing research on sensitive topics", Sage, London, UK. Mayrhofer, W., Reichel, A., Sparrow, P. (2012) "Chapter 15: Alternative Forms of International Working", In: Stahl, G. K., Björkman, I. Morris, S. (eds.) "Handbook of Research in International Human Resource Management", Edward Elgar Publishing Limited, Cheltenham, UK, pp. 300-327. https://doi.org/10.4337/9781849809191.00021

Muncey, T. (2005) "Doing Autoethnography", International Journal of Qualitative Methods, 4(1), pp. 69-86. https://doi.org/10.1177/160940690500400105

Okumus, F., Altinay, L., Roper, A. (2007) "Gaining access for research: Reflections from Experience", Annals of Tourism Research, 34(1), pp. 7-26. https://doi.org/10.1016/j.annals.2006.07.006

Quattrone, P. (2006) "The Possibility of the Testimony: A Case for Case Study Research", Organization, 13(1), pp. 143-157. https://doi.org/10.1177/1350508406059647
Ragin, C. C., Becker, H. S. (1992) "What is a case? Exploring the foundations of social inquiry", Cambridge University Press, Cambridge, UK

Reeves, C. L. (2010) "A difficult negotiation: fieldwork relations with gatekeepers", Qualitative Research, 10(3), pp. 315-331. https://doi.org/10.1177/1468794109360150

Riessman, C. K. (1993) "Narrative analysis", Sage Publications, Newbury Park, CA, USA.

Shaffer, M. A., Kraimer, M. L., Chen, Y. P., Bolino, M. C. (2012) "Choices, Challenges and Career Consequences of Global Work Experiences: A Review and Future Agenda", Journal of Management, 38(4), pp. 1282-1327. https://oi.org/10.1177/0149206312441834

Shenton, A. K., Hayter, S. (2004) "Strategies for gaining access to organizations and informants in qualitative studies", Education for Information, 22(3-4), pp. 223-231. https://doi.org/10.3233/EFI-2004-223-404

Siwale, J. (2015) "Why Did I Not Prepare for This? The Politics of Negotiating Fieldwork Access, Identity, and Methodology in Researching Microfinance Institutions", SAGE Open, 5(2), pp. 1-12. https://doi.org/10.1177/2158244015587560

Thomas, R. J. (1993) "Interviewing Important People in Big Companies", Journal of Contemporary Ethnography, 22(1), pp. 80-96. https://doi.org/10.1177/089124193022001006

Wall, S. (2006) "An Autoethnography on Learning About Autoethnography", International Journal of Qualitative Methods, 5(2), pp. 146-160. https://doi.org/10.1177/160940690600500205

Welch, C., Marschan-Piekkari, R., Penttinen, H., Tahvanainen, M. (2002) "Corporate elites as informants in qualitative international business research", International Business Review, 11(5), pp. 611-628. https://doi.org/10.1016/S0969-5931(02)00039-2 